\title{
Typology and Preventive Strategies of Accident in Technical College Workshops in Kwara and Kogi States
}

\author{
Abiodun, E. OGUNMOLA ${ }^{1}$ \\ ${ }^{1}$ Department of Vocational Education, Faculty of Education, Nnamdi Azikiwe University, Nigeria \\ Correspondence: Abiodun, E. OGUNMOLA, Department of Vocational Education, Faculty of Education, \\ Nnamdi Azikiwe University, Nigeria. E-mail: he.adebola@unizik.edu.ng
}

Received: August 7, 2018; Accepted: August 27, 2018; Published: October 29, 2018

\begin{abstract}
This study investigated the typology and preventive strategies of accidents in technical college workshops in Kwara and Kogi States. Three research questions were posed and two hypotheses were formulated for the study. A descriptive research design was employed. The area of the study was Kwara and Kogi states. A total of 793 technical teachers made up the population of the study, while stratified random sampling was used to select the sample which was 397. Research instrument was a questionnaire named 'Questionnaire on Typology and Preventive Strategies of Accidents in Technical College Workshop (QTPSATCW)'. Three experts validated the instrument and a reliability test using Cronbach Alpha method yielded 0.92. Mean rating was used to answer the research questions while z-test at 0.05 level of significance was used to test the hypotheses. The findings among others revealed that cuts from sharp objects, scratches, crushing of the toe or heel by objects, piercing of foot or hand by sharp objects, eye injury, hitting/cutting of the finger with tools, burns from hot objects (e.g. oven, forge), fall from height and electric shock are some of the types of accidents that could occur in technical workshops in Kwara and Kogi States. There exists no significance difference in the mean ratings of male technical teachers and female technical teachers of strategies that could be adopted to prevent accidents in technical college workshops. Based on the findings, recommendations were made among which were that technical teachers should organize the workshop activities with good housekeeping and that government should ensure availability of training equipment in adequate quantity and quality to commensurate with students' ratio in technical college workshops.
\end{abstract}

Keywords: typology, preventive strategies, accidents, technical, workshops

\section{Introduction}

The fundamental emphasis of technical and vocational education programme is skills development. Technical education borders on acquisition of knowledge and skills in trades like woodwork, metalwork, electrical installations, electronics, block/bricklaying and concreting, welding and fabrication, fitting and machining and auto-mechanics. Other trades are carpentry and furniture crafts, painting and decorating; and plumbing works. The skills are necessary for employment and help workers to update and upgrade their job performance so as to retain their jobs in both the private and public sectors of the economy. Such skills include fitting, machining, milling, jointing and cutting skill among others. This is consistent with the National Policy on Education (Federal Republic of Nigeria, 2013), which provides that one of the prime objectives of vocational and technical education is to give training and impart the necessary skills leading to the production of craftsmen, technicians and skilled personnel who will be enterprising and self-reliant. Ogalanya (2000) states that technology education helps to provide adequate skills, knowledge and practical experiences to individuals with a wide range of abilities.

Yayirus (2003) observed that practical skills are not just acquired in the open field; rather they are developed in the workshops or laboratories replete with appropriate tools, equipment and other necessary facilities. Odu (2011) stated that hand tools, machines and instructional material facilities may be available in abundance but without well trained technical teachers to manage these facilities, learning cannot take place. Technical teachers consist of trained teachers in different areas of technology such as electrical/electronic, building, woodwork, plumbing, carpentry and joinery, auto mechanics and metalwork. Technical teachers, males and females alike, are those that give the training and transmit the facts, knowledge, skills, and attitudes, and to the learners within the instructional system and as may be applied to the world of work. The workshop is where the interactions take place.

Okorie (2001) explained that technical college workshop is a place where the learner may experiment, test, construct, dismantle, repair, design, create, imagine and study using workshop equipment. Technical college 
equipment include lathe machines, shaping machines, rolling machines, drilling machines, cutting machines, welding machines, circular saw, guillotine and various hand tools such as hacksaws, files, pincers, pliers, drills, soldering iron, and spanners that are required for imparting practical knowledge and skills to the students. Workshops also contain a wide variety of toxics, inflammables, corrosive or reactive compounds such as sulphuric acids and oxyacetylene. In the process of trying to use these machines and materials, accident could occur; therefore workshop users(both technical personnel and students) are prone to accidents.

In human settlements, urban stands for an area that is characterized by human population and vast human built infrastructures while rural areas have a low population and small settlement with few infrastructures. Health, education, employment, and development facilities are thousands times better in urban as compared to rural areas. This wholesome situation seems to have detracted qualified teachers from working in rural areas. Obasi (2011) reported that urban schools have more concentration of qualified graduate teachers; students of the same subjects in rural schools are compelled to make do with either unqualified teachers or none at all. Perhaps the differences in opportunities offered for the imparting and acquiring skills in both urban and rural environment affect workshop accidents.

Okeke and Oranu (2006) noted that wherever tools and machines are used, accidents will likely occur despite the best efforts. Accident may be defined as an undesirable, unplanned, un-controlled event or a sudden miss-hap which interrupts an activity or function and could result in physical harm to person(s) or damage to property or equipment.

Offonmbuk and Ekereobong (2012) reported that accidents are common in technical college workshops. This supported Olateju (2005) who revealed that accidents often occur in vocational and technical education workshops. Olateju listed such accidents to include electric-shock, cuts from sharp objects, eye injury, burns of various degrees, and fall from heights, slips, and fire incidence. There were instances where technical teachers and students were reported to be disabled as a result of workshop accidents. Accidents can be classified according to the types of accidents, characteristics and traits. This is what is referred as typology of accidents. There are various types of workshop accidents among which are injury from sharp objects, body injury from damaged or unguarded equipment/tools, contact of acidic or corrosive chemicals on the physical body, toxic gas emitting and inhalation, electrocution, electric shock, suffocation and fall from height.

Accidents interfere with lessons and decimate manpower and material resources; thus disorganizing the workshop activities. From economic view point, accidents are costly events which seriously hamper production. Often machineries and equipment involved in an accident are damaged resulting in expensive cost for replacement or improvisation. The realities of globalization and technological advancement earnestly call for turning out skilled workers who can flexibly acquire, apply and transfer their knowledge to varying technological conditions (Ogwo, 2005). Occurrence of accidents in technical college workshop could hinder the achievement of this worthwhile objective. Hence, there is the need to determine the types of accidents, causative factors and strategies that could be adopted to prevent accidents in technical college workshops in Kwara and Kogi states.

Technical and vocational educational programmes involve practical training in workshops, which call for the use of tools, equipment, machines and materials. This training is expected to take place in a workshop that is free of hazards. Practical activities in technical college workshops such as; welding, drilling, battery charging, spraying, and forging expose users to possible unsafe situations. In addition, by acts of omission or commission, users jeopardize the entire working environment. As a result, accidents do occur and cause injuries to technical teachers, students and workshop assistants (Olateju, 2005). These turn the workshop from a work-friendly environment to an unfriendly and hazardous environment.

The main purpose of this study was to determine the typology, causative factors and strategies for preventing accidents in technical college workshops in Kwara and Kogi States. Specifically, the study was designed establish the:

1. Types of accidents that could occur in technical college workshops in urban areas of Kwara and Kogi States.

2. Types of accidents that could occur in technical college workshops in rural areas of Kwara and Kogi States.

3. Strategies that could be adopted to prevent accidents in technical college workshops in Kwara and Kogi States.

\section{Research Questions}

The following research questions guided the study:

1. What types of accidents could occur in technical college workshops in urban areas of Kwara and Kogi States?

2. What types of accidents could occur in technical college workshops in rural areas of Kwara and Kogi States? 
3. What are the strategies that could be adopted to prevent accidents in technical college workshops in Kwara and Kogi States?

\section{Hypotheses}

The following null hypotheses were tested at 0.05 level of significance:

1. Technical teachers in urban and rural areas do not differ significantly in their mean ratings on the type of accidents that could occur in technical college workshops in Kwara and Kogi States.

2. There is no significant difference in the mean ratings of male and female technical teachers of the strategies that could be adopted to prevent accidents in technical college workshops in Kwara and Kogi States.

\section{Method}

The design used for this study is the descriptive survey design. The population of this study consisted of the 793 teachers in all the technical colleges in the area of study. The sample for the study was 397 technical teachers. Stratified random sampling technique was used to obtain the sample. All the 10 technical colleges in the two states were used. The colleges were stratified into urban and rural areas and 50 percent of the population of technical teachers in each college were randomly selected. A total of 197 technical teachers in Kwara State and 200 technical teachers in Kogi State were used for the study, making it 397 respondents. The researcher developed the questionnaire named 'Questionnaire on Typology and Preventive Strategies of Accidents in Technical College Workshops (QTPSATCW) which was the instrument used for data collection. The Likert scale was adopted for the instrument with five response options of: Strongly Agree $(\mathrm{SA})=4$; Agree $(A)=3$; Disagree $(\mathrm{D})=2$; and Strongly Disagree $(\mathrm{SD})=1$.

To validate the instrument, copies of the research topic, purpose of study, research questions and hypotheses together with the draft instrument were given to two experts in technical education and one expert in measurement and evaluation all from the Faculty of Education, Nnamdi Azikiwe University, Awka. The reliability of the instrument was determined by distributing 20 to randomly selected technical teachers from Federal Government Science and Technical College, Awka and Government Technical College, Utuh in Anambra State. The data collected were anaylized with Cronbach Alpha statistics. The reliability co-efficient values obtained were 0.93 , $0.93,0.91$ and 0.93 . The overall instrument yielded reliability co-efficient of 0.92 which was considered high and acceptable for the study.

The researcher prepared 10 research assistants who helped him to personally distribute 397 copies of the instrument to the respondents in the two states. Some respondents completed the questionnaire on the spot and they were retrieved but in most cases where on the spot completion or retrieval were not possible, therefore, the researcher and assistants re-visited the concerned respondents on agreed dates for retrieval. In all, 385 copies of the questionnaire (representing 97 percent) were retrieved and used for the study. The data collected from the respondents were collated and analysed using the mean, the standard deviation. The mean was used to analyse the data related to the research questions while z-test was used to test the hypotheses at 0.05 level of significance.

The decision rule for the research questions was based on the mean rating of 3.00. Therefore, items with mean rating of 3.00 was agreed, while items with mean rating less than 3.00 was disagreed. Standard deviation was applied to measure dispersion of respondents' responses on the mean values of their responses. The smaller the standard deviation, the more homogeneous their responses are. A hypothesis was accepted where the calculated ztest value is less than the critical table value and it was rejected where the calculated $z$-value is equal to or greater than critical z-value.

\section{Research Question 1}

What types of accidents could occur in technical college workshops in urban areas of Kwara and Kogi States?

Table 1. Respondents' Mean Ratings and Standard Deviations on Types of Accidents that could occur in Technical College Workshops in Urban Areas of Kwara and Kogi States ( $\mathrm{N}=385)$

\begin{tabular}{lllll}
\hline S/N & Type of Accidents & $\boldsymbol{X}$ & S.D & Remark \\
\hline 1 & Struck by falling objects & 3.75 & 1.19 & Agree \\
2 & Fall from height & 3.21 & 1.35 & Agree \\
3 & Electric shock & 4.19 & 1.09 & Agree \\
4 & Trips and fall & 3.16 & 1.43 & Agree \\
5 & Slips and fall & 4.27 & 0.09 & Agree \\
\hline
\end{tabular}




\begin{tabular}{lllll}
\hline 6 & Burns from chemical splash & 3.03 & 1.64 & Agree \\
7 & Burns from electric flash & 3.9 & 1.14 & Agree \\
8 & Burns from hot object (e.g oven, forge) & 4.19 & 0.99 & Agree \\
9 & Cuts from sharp object & 4.23 & 1.07 & Agree \\
10 & Scratches & 3.65 & 1.26 & Agree \\
11 & Crushing of the toe or heel by objects & 4.16 & 0.89 & Agree \\
12 & Piercing of foot or hand by sharp object & 4.44 & 0.77 & Agree \\
13 & Fracture of the limbs & 3.25 & 1.34 & Agree \\
14 & Fire incidence & 3.51 & 1.38 & Agree \\
15 & Eye injury & 3.82 & 1.21 & Agree \\
16 & Inhalation of fumes/gas & 3.49 & 1.18 & Agree \\
17 & Electrocution & 3.03 & 1.17 & Agree \\
18 & Contact with rotating/revolving parts & 3.52 & 1.25 & Agree \\
19 & Amputation & 2.14 & 1.13 & Disagree \\
20 & Hitting/cutting of finger with tools & 3.64 & 1.19 & Agree \\
& Mean of Mean/SD & 3.63 & $\mathbf{1 . 1 4}$ & Agree \\
\hline
\end{tabular}

The results of data presented in Table 1 show data of technical teachers' rating of types of accidents that could occur in technical college workshops in urban areas. Out of the 20 items listed, 19 items have their mean ratings higher than the cut off mean of 3.00 .

This means that the respondents agreed that the listed types of accidents could occur in technical college workshops in urban areas. On the other hand the mean rating of item 19 is less than the cut off mean of 3.00. This means that the technical teachers do not agree that amputation could occur in technical college workshops in urban areas.

\section{Research Question 2}

What types of accidents could occur in technical college workshops in rural areas of Kwara and Kogi States.

Table 2. Respondents' Mean Ratings and Standard Deviations on types of accidents that could occur in Technical College Workshops in rural areas of Kwara and Kogi States ( $\mathrm{N}=385)$

\begin{tabular}{lllll}
\hline S/N & Type of Accidents & $\boldsymbol{X}$ & S.D & Remark \\
\hline 1 & Struck by falling objects & 3.74 & 0.97 & Agree \\
2 & Fall from height & 3.66 & 1.07 & Agree \\
3 & Electric shock & 4.19 & 1.09 & Agree \\
4 & Trips and fall & 3.00 & 1.43 & Agree \\
5 & Slips and fall & 3.31 & 1.45 & Agree \\
6 & Burns from chemical splash & 3.48 & 1.37 & Agree \\
7 & Burns from electric flash & 3.51 & 1.57 & Agree \\
8 & Burns from hot object (e.g oven, forge) & 3.75 & 1.13 & Agree \\
9 & Cuts from sharp object & 4.04 & 1.09 & Agree \\
10 & Scratches & 3.47 & 1.00 & Agree \\
11 & Crushing of the toe or heel by objects & 3.54 & 0.96 & Agree \\
12 & Piercing of foot or hand by sharp object & 4.01 & 0.72 & Agree \\
13 & Fracture of the limbs & 3.27 & 1.02 & Agree \\
14 & Fire incidence & 3.60 & 1.38 & Agree \\
15 & Eye injury & 3.44 & 1.35 & Agree \\
16 & Inhalation of fumes/gas & 3.41 & 1.15 & Agree \\
17 & Electrocution & 3.05 & 1.40 & Agree \\
18 & Contact with rotating/revolving parts & 3.32 & 1.05 & Agree \\
19 & Amputation & 2.46 & 1.15 & Disagree \\
20 & Hitting/cutting of finger with tools & 3.44 & 1.28 & Agree \\
\hline & Mean of Mean/SD & $\mathbf{3 . 4 8}$ & 1.18 & Agree \\
\hline
\end{tabular}

The results of data presented in Table 2 show data of technical teachers' rating of types of accidents that could occur in technical college workshops in rural areas. Out of the 20 items listed, 19 items have their mean ratings 
higher than the cut off mean of 3.00. This means that the respondents agreed that the listed types of accidents could occur in technical college workshops in rural areas.

On the other hand, the mean rating of item 19 is less than the cut off mean of 3.00. This means that the technical teachers do not agree that amputation could occur in technical college workshops in rural areas.

\section{Research Question 3}

What are the strategies that could be adopted to prevent accidents in technical college workshops in Kwara and Kogi States?

To answer this question, the relevant data were analysed and results obtained are shown in Table 3.

Table 3. Strategies that could be adopted to Prevent Accidents in Technical College Workshops $(\mathrm{N}=385)$

\begin{tabular}{lllll}
\hline S/N & Strategies & $\overline{\boldsymbol{X}}$ & $\mathbf{S . D}$ & Remark \\
\hline 21 & Hazard identification and reporting & 4.18 & 0.98 & Agree \\
22 & Effective supervision & 4.11 & 0.89 & Agree \\
23 & Compliance with safety rules andregulation & 4.32 & 0.93 & Agree \\
24 & Management Commitment & 4.09 & 0.81 & Agree \\
25 & Routine inspection and maintenance & 4.32 & 0.81 & Agree \\
26 & Use of safety tips and flyers & 4.09 & 0.90 & Agree \\
27 & Accident investigation and reporting & 4.10 & 0.98 & Agree \\
28 & Regular safety meetings & 4.08 & 0.78 & Agree \\
29 & Fortified first aid box & 3.99 & 1.04 & Agree \\
30 & Adequate waste disposal unit & 4.05 & 0.85 & Agree \\
31 & Provision of accident statistic board & 4.02 & 0.90 & Agree \\
32 & Good housekeeping & 4.21 & 0.72 & Agree \\
33 & Provision of adequate tools and & 4.16 & 0.84 & Agreels \\
34 & Provision of standard safety devices & 4.24 & 0.87 & Agree \\
& Mean of Mean/S.D & $\mathbf{4 . 1 4}$ & $\mathbf{0 . 8 8}$ & Agree \\
\hline
\end{tabular}

The results of data presented in Table 3 show the mean scores and standard deviation of respondents' rating of strategies that could be adopted to prevent accidents in technical college workshops. All the items have their mean rating values above 3.00 with highest mean rating value of 4.32 and least mean rating value of 3.99 . They are therefore accepted. This was further confirmed by the grand mean and standard deviation of 4.14 and 0.88 respectively.

\section{Test of Hypotheses}

The hypotheses formulated for the study were tested in this section. The z-test statistical was used for analysing data the relating to the hypotheses at 0.05 level of significance.

$\mathrm{HO}_{1:}$ There is no significant difference in the mean ratings of more experienced and less experienced technical teachers on the types of accidents that could occur in technical college workshops.

The test of hypothesis 1 is presented in table 4 .

Table 4. z-Test of significance difference between Urban and Rural Technical Teachers of Types of Accidents that could occur in Technical College Workshops

\begin{tabular}{llllllll}
\hline Group & $\mathrm{N}$ & $\overline{\boldsymbol{X}}$ & $\mathrm{SD}$ & $\mathrm{df}$ & z-cal & z-critical & Remark \\
\hline Urban & 317 & 3.49 & 1.19 & 383 & 1.56 & 1.96 & Accepted \\
Rural & 68 & 3.73 & 1.14 & & & & \\
\hline
\end{tabular}

Table 4 presented the z-test summary of the mean rating values of urban and rural technical teachers on types of accidents that could occur in technical college workshops. From the analysis, it can be observed that the mean for the urban technical teacher was 3.49 and that of the rural technical teachers was 3.73. The standard deviations were 1.19 and 1.14 respectively. 
The calculated z-value was 1.56 and the critical z-value was 1.96. Since the calculated z-value of 1.56 is less than the critical z-value of 1.96 at 0.05 level of significance. This indicates that more experienced and less experienced technical teachers did not differ significantly on the types of accidents that could occur in technical college workshops. The hypothesis is accepted.

$\mathrm{HO}_{2}$ : There is no significant difference in the mean ratings of male and female technical teachers of strategies that could be adopted to prevent accidents in technical college workshops.

Table 5. z-test Summary of Mean Rating of Male and Female Technical Teachers of Strategies that could be adopted to Prevent Accidents in Technical College Workshops

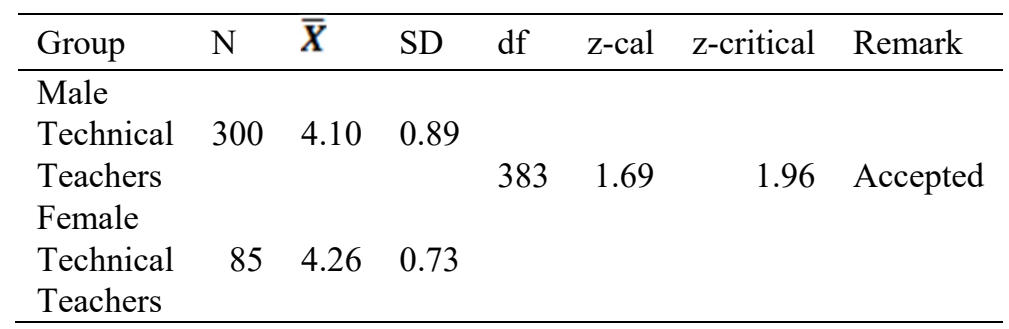

Table 6 presented the z-test analysis of the mean rating values of male and female technical teachers of strategies that could be adopted to prevent accidents in technical college workshops. From the analysis, it can be observed that the mean for the male technical teacher was 4.10 and that of the female technical teachers was 4.26 . The standard deviations were 0.89 and 0.73 respectively.

The calculated z-value was 1.69 and the critical z-value was 1.96. Since the calculated z-value of 1.69 is less than the critical z-value of 1.96 at 0.05 level of significance, the null hypothesis is accepted and the alternative rejected. This means that there exists no significant difference in the mean ratings of male technical teachers and female technical teachers of strategies that could be adopted to prevent accidents in technical college workshops.

\section{Discussion}

With respect to research question one and two which were presented in Tables 1 and 2 which sought to identify the types of accidents that could occur in technical college workshops in urban and rural areas, findings indicated that cuts from sharp objects, scratches, crushing of the toe or heel by objects, piercing of foot or hand by sharp objects, eye injury, hitting/cutting of the finger with tools, burns from hot objects (e.g. oven, forge), fall from height and electric shock could occur. These findings corresponded to those of Okeke and Oranu (2006); Uwaifo (2009); Offomnbuk and Ekereobong (2012); Kadiri (2006) and Olateju (2005). The authors listed electric shock, slips and fall, burn from hot metals, cuts and eye injury as accidents that do occur in technical college workshops. It was also found out that amputation could not occur in technical college workshops. This is in disagreement with Okeke and Oranu (2006) who had listed amputation as part of accidents in vocational technical education workshops.

The finding of the study further revealed that among the strategies that could be adopted to prevent accidents in the technical college workshops are compliance with safety rules and regulations, provision of standard safety devices, provision of adequate tools and materials, routine inspection and maintenance, good housekeeping and management commitment. This is in agreement with Omotayo (1996) who revealed that accidents prevention and reduction in technical college workshop are possible if necessary facilities and safety strategies are put in place. This researcher believes that provision of adequate tools and materials, standard safety devices; accidents statistic board and safety flyers are good strategies to prevent accidents. An automatic circuit breaker if installed on a machine could help prevent electric shock or fire outbreak when fault occurs in the machine. Also, a safety guard on a machine will serve as an obstacle that prevent a worker from touch dangerous area of the machine (like rotating shaft, gear or belt). The testing of hypothesis 2 revealed that the null hypothesis was accepted. This means that there exist no significance difference in the mean ratings of male technical teachers and female technical teachers on strategies that could be used to prevent accidents in technical college workshops. This finding shows clearly that these strategies are not gender biased. What this implies is that the strategy a male teacher would use to prevent accident in technical college workshop could also be used for the same purpose by a female teacher. 


\section{Conclusion}

It was concluded that the types of accident that could occur in technical college workshops among others are cuts from sharp objects, scratches, eye injury, burns, fall from height and electric shock. Some strategies such as provision of adequate tools and materials, routine inspection, good housekeeping, recruitment of quality and quantity technical teachers could be adopted to prevent accident in technical college workshops.

Based on the findings, it was recommended that:

1. Implementation of technical education curriculum requires good manipulating skill-oriented instructional facilities in a conducive learning environment. Government should therefore ensure availability of training equipment/tools in adequate quantity and quality to commensurate with students' ratio in each technical college to ensure students proper participation in an accidents-free workshop.

2. Management of technical colleges should ensure that teacher/students' ratio is reduced. They should also ensure that technical teachers constantly update their knowledge/skills through seminars, and educational advancement in order to keep abreast of new technologies.

3. Technical teachers should organize the workshop activities with good housekeeping in the issuance and use of materials, tools and equipment, maintenance of the workshops.

4. Technical teachers should present safety instructions and demonstrate the use of each equipment to student before workshop practice is allowed.

5. The findings of this study also revealed that students need proper supervision when on workshop practice. It is therefore recommended that technical teachers should never be out of workshop during workshop practice to avoid unauthorized operations and horseplay.

\section{Acknowledgements}

The researcher is grateful to the following people in the Department of Vocational Education: Profs. T. I. Eze, K. R. E, Okoye, O. T. Ibeneme and Dr. H. E. Adebola who contributed to the success of the research.

\section{References}

Dolan, J. A. (2000). Motor vehicle technology and practical work. London: Heinnerman Edward Book Ltd.

Federal Republic of Nigeria. (2013). National policy on education (6 $6^{\text {th }}$ ed.) Abuja: Nigerian Education Research and Development CouncilPress.

Kadiri, S. A. (2006). Safety handbook for engineering and allied professionals. Lagos: Zub-Chord Technical Ventures.

Nwaifo, V. O. (2009). Better be safe than be sorry: An analysis of workshop behaviour in vocational and technical schools. International NGO Journal, 4(9), 386-390. Retrieved July 25, 2013, form https://www.academicjournals.org

Obasi, M. N. (2011). Urban-Rural differential in teaching and learning of geography in Ahiuzu Mbaise and Owerri municipal council in Imo State. Environmental Research Journal, 5(4), 140-148. https://doi.org/10.3923/erj.2011.140.148

Odu, K. O. (2011). Human capital development in science and technology education: Challenges and new responsibilities of the teachers. Journal of Comtemporary Educational Technology, 2(3), 238-249.

Ofonmbuk, I. M., \& Ekereobong, S. U. (2012). School workshop safety practices and students' skill acquisition in electrical installation works in technical colleges in Akwa Ibom State. Mediterranean Journal of Social Sciences, 3(13), 118.

Ogalanya, G. A. O. (2000). Improving course content of technical colleges in order to enhance self-reliance. The imperative of vocational and technical education for a developing nation. Onitsha: Cape publishers.

Ogwo, B. A. (2005). Effects of meta-learning instructional strategies on students'achievement in metalwork technology. Unpublished Doctoral Dissertation. Department of Vocational Teacher Education. University of Nigeria, Nsukka.

Okeke, B. C., \& Oranu, R. N. (2006). Principle and practice in the management of industral, vocational and technical workshop. Onitsha: Base five Publishers.

Okorie, J. U. (2001). Vocational industrial education. Bauchi: League of Researchers in Nigeria.

Olateju, A. S. O. (2005). Accident occurrences and prevention in vocational technical education workshops for 
sustanaible skill development. National Association of Teachers of Technology, 5(2), 132-138.

Omotayo, A. O. (1996). The Relationship between safety instruction and Accident prevention in technical colleges laboratories in Edo State. Unpublished Research Work, Department of Vocational Teacher Education, University of Nigeria, Nsukka.

Uwaifo, V. O. (2009). Better be safe than be sorry: An analysis of workshop behaviour in vocational and technical schools. Academic Journal, 4(9), 386-390.

Yayirus, B. (2003). Facilities utilization in Adamawa State technical colleges. An unpublished M. Ed. Thesis. University of Nigeria, Nsukka.

\section{Copyrights}

Copyright for this article is retained by the author(s), with first publication rights granted to the journal.

This is an open-access article distributed under the terms and conditions of the Creative Commons Attribution license (http://creativecommons.org/licenses/by/4.0/). 